\title{
RECOVERY OF HYDROCHLORIC ACID FROM ION EXCHANGE PROCESSES BY REACTIVE ELECTRODIALYSIS
}

\author{
G. CIFUENTES ${ }^{\prime *}$, N. GUAJARDO ${ }^{1}, J$. HERNÁNDEZ ${ }^{2}$ \\ ${ }^{1}$ Departamento de Ingeniería Metalúrgica, Universidad de Santiago de Chile, Santiago, Chile, \\ ${ }^{2}$ Sección de Geología y Minería, Comisión Chilena de Energía Nuclear, Amunátegui 95, Santiago, Chile
}

\begin{abstract}
The purification process of electrolytes contaminated from electrorefining consists in placing them in contact with an ion exchange resin which can function continuously due to its reconditioning with hydrchloric acid. The treatment of the resultant solution, known as elution, consists in doing a fractional distillation releasing hydrochloric acid and gaseous chlorine. The release of these represents most of the operational problems in the electrolyte treatment plant. This paper proposes an alternative to this distillation process, using a reactive electrodialysis cell and cation and anion exchange membranes.
\end{abstract}

Keywords: Reactive electrodialysis, hydrochloric acid, chloride ions.

\section{INTRODUCTION}

The reserves of Ministro Hales division of Codelco are estimated in 1,300 million tons of copper sulfide ores, with a mean richnesss of $0.96 \%$. The final product obtained will be processed at the Chuquicamata smelter and refinery ${ }^{1}$.

The problem is that this ore contains antimony and bismuth impurities that cannot be eliminated by smelting, so they will remain in the system until the electrorefining where the copper present in the anode dissolves in the electrolyte, together with antimony and bismuth which contaminate the solution and affect the quality of the resultant cathode.

The quality of electrolytic copper is one of the greatest concerns in refining, and that is why the impurity levels have great importance in achieving this objective. In particular, antimony and bismuth have standard reaction potentials similar to that of copper, as can be seen in Table 1.1. Both having similar requirements to react energy can do so in different ways, either depositing on the cathode or forming floating slime. For this reason they are considered harmful impurities, not only because of their influence on the characteristics of the copper cathode obtained, but because of the difficulty to control them. The effect of these elements is harmful to the physical properties of the copper cathode.

Table 1.1.- Potentials of the reduction reactions of copper, antimony and bismuth.

\begin{tabular}{|c|c|}
\hline Semi-reaction & Potential ( $\left(\mathrm{V}_{\mathrm{NHE}}\right)$ \\
\hline $\mathrm{Cu}^{2+}+2 e^{-} \Rightarrow \mathrm{Cu}^{0}$ & 0.337 \\
\hline $\mathrm{BiO}+2 \mathrm{H}^{+}+3 e^{-} \Rightarrow \mathrm{Bi}+\mathrm{H}_{2} \mathrm{O}$ & 0.320 \\
\hline $\mathrm{SbO}^{+}+2 \mathrm{H}^{+}+3 e^{-} \Rightarrow \mathrm{Sb}+\mathrm{H}_{2} \mathrm{O}$ & 0.212 \\
\hline
\end{tabular}

The process used at present to remove the antimony and bismuth consists in contacting the copper electrorefining electrolyte with an ion exchange resin that captures the impurities and allows the recirculation of the clean electrolyte back to the electrorefining. Then it is necessary to regenerate that same resin to reuse it, so it is contacted with hydrochloric acid. This elution process regenerates the resin by ion exchange between the proton and the impurities captured on the resin, so that the process is cyclic.

After the ion exchange stages, fractional distillation is used to recover the acid from the eluting solution. In this way, gaseous $\mathrm{HCl}$ and $\mathrm{Cl}_{2}$ are obtained, both very corrosive and harmful to health, so they require very careful control during the operation.

To recover the hydrochloric acid from the eluting solution we propose to replace the fractional distillation stage by reactive electrodialysis, where the recovery will take place by the flow of chloride ions from the eluting solution to the anode compartment, and the oxidation of water reaction.
Electrodialysis

Electrodialysis is the procedure for the purification or concentration of solutions by applying a potential difference and the separation of the compartments by means of one or more ion exchange membranes (EM) which have the quality of allowing selectively the passage of ions through them, with the cationic (CEM) allowing the passage of cations, and the anionic (AEM) allowing the passage of anions. The name reactive electrodialysis (RED) is used when the products of interest are formed by electrochemical reactions ${ }^{2,3,4,5}$.

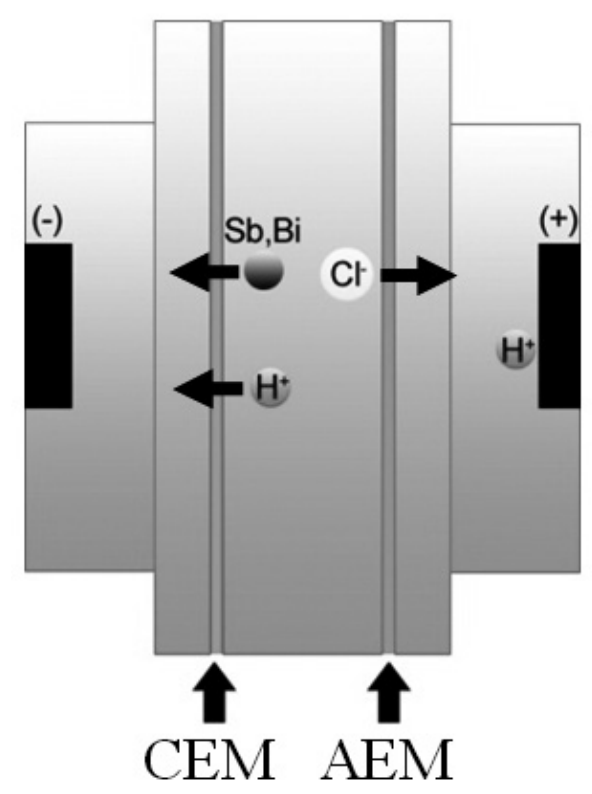

Figure 1.1. Schematic of the RED cell used in the experiment.

In this system a cationic membrane will be used to separate the catholyte and the eluting solution, allowing the passage of antimony and bismuth ions, and of protons, as shown in Figure 1.1. In turn, an anionic membrane will be used to allow the passage of chloride ions from the eluting solution to the anolyte. Protons will be produced at the anode from the oxidation of water, so hydrochloric acid will be formed.

The flow of ions in an electrochemical system is given by the NernstPlanck equation: 


$$
N_{i}=-D_{i} \cdot\left[\frac{d c_{i}}{d x}+z_{i} \cdot c_{i} \cdot \frac{F}{R \cdot T} \cdot \frac{d \varphi}{d x}\right]+c_{i} \cdot v
$$

where

- $\quad N_{i}$ : Total ion flow in a solution per unit area and time.

- $\quad-D_{i} \cdot \frac{d c_{i}}{d x}$ : Flow of ions by diffusion.

- $\quad-D_{i} \cdot z_{i} \cdot c_{i} \cdot \frac{F}{R \cdot T} \cdot \frac{d \varphi}{d x}$ : Flow of ions by migration.

- $\quad c_{i} \cdot v$ : Flow of ions by convection.

Equation (1) shows that the flow of ions in any system is due to any of the just mentioned motor forces: diffusion, convection, and migration ${ }^{6,7,8,9,10,11}$.

Reactive electrodialysis is used because chloride ions in particular have a large radius compared to most of the species, so the flow of ions by diffusion is low. For that reason the main ion flow mechanism is migration.

\section{EXPERIMENTAL PROCEDURE}

To carry out the RED use was made of a main circuit with three equal sections that contain the working solutions, and a secondary circuit whose purpose is to heat the electrolytes by circulating hot water. Figure 2.1 shows the diagram of the system used.

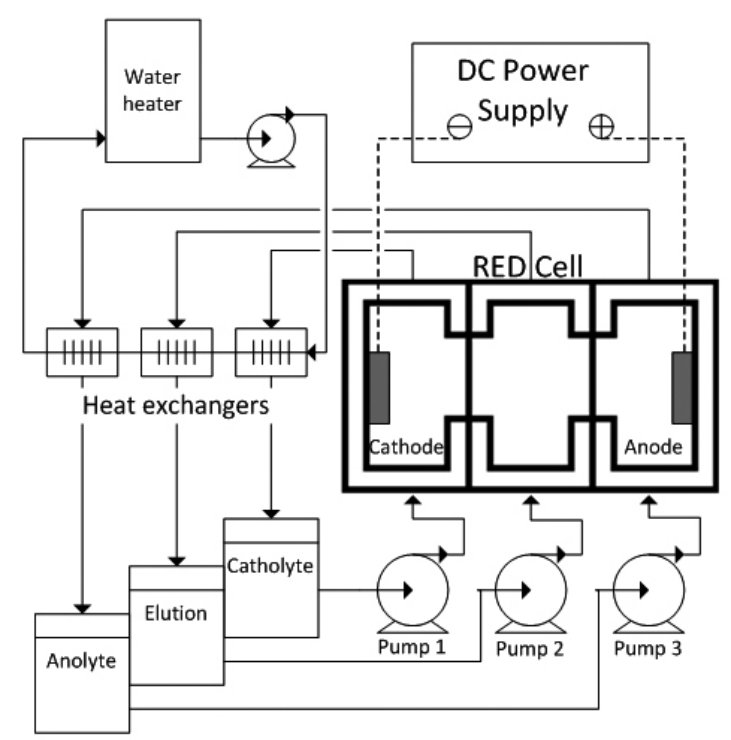

Figure 2.1.- Diagram of the RED system.

Approximately $1000 \mathrm{~cm}^{3}$ of each solution were used. The pumps delivered a flow of $1 \mathrm{~L} / \mathrm{min}$, achieving good agitation both in the cell and in the storage containers. The initial concentrations of the solutions were $0.5 \mathrm{M} \mathrm{NaCl}$ for the anolyte, $6 \mathrm{~N} \mathrm{HCl}$ for the eluting solution, and $1 \mathrm{M} \mathrm{H}_{2} \mathrm{SO}_{4}$ for the catholyte. The working temperatures were 20,30 and $40{ }^{\circ} \mathrm{C}$. The test times were 5 and 12 hours.

The cathode was a $38 \times 28 \mathrm{~mm}$ stainless steel plate with an effective area of $744 \mathrm{~mm}^{2}$. The anode was a graphite block $48 \times 38 \times 18 \mathrm{~mm}$, with an effective area of $1000 \mathrm{~mm}^{2}$. The reverse side of both electrodes was coated with silicone to improve the adhesion of the cell and avoid leakage. The relevant current density in this system is the anodic, because work must be done mainly with the reaction of water to oxygen, avoiding the formation of gaseous chlorine from the chloride ions. Current densities of 300,400 and $500 \mathrm{~A} / \mathrm{m}^{2}$ were used in this experiment.

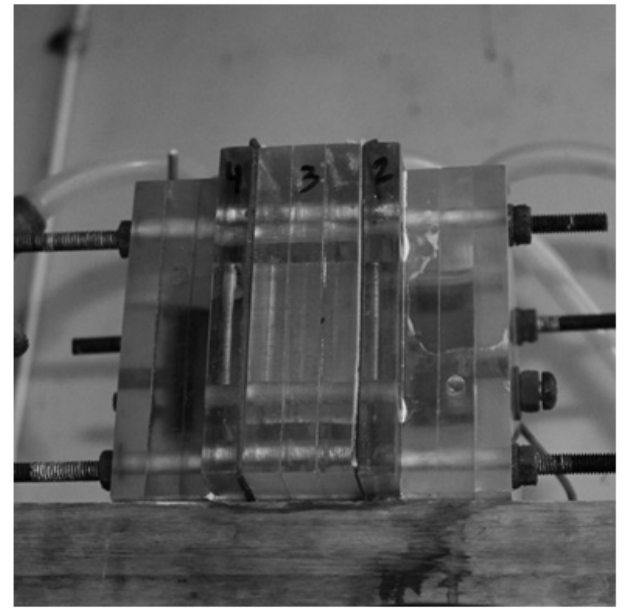

Figure 2.2.- Cell used for the reactive electrodialysis.

The RED cell consisted of 3 compartments, with two ion exchange membranes as separation medium, attached to eva rubber sheets. A Hydrodex HDX100 (cationic) membrane was used between the cathode and the elution compartment (central), and a Hydrodex HDX200 membrane (anionic) between the central piece and the anodic compartment, to allow the passage of chloride ions to the anolyte ${ }^{12}$.

\section{RESULTS AND DISCUSSION}

The results are presented in tables 3.1 to 3.3 and in the figures that follow:

Tabla 3.1.- Experimental results obtained with a flow rate of $1 \mathrm{~L} / \mathrm{min}$ and a testing time of 5 hours.

\begin{tabular}{|c|c|c|c|c|c|}
\hline $\begin{array}{c}\text { Test } \\
\text { No. }\end{array}$ & $\mathrm{T}^{\circ} \mathrm{C}$ & $\begin{array}{c}\text { Current } \\
\text { density } \\
\left(\mathrm{A} / \mathrm{m}^{2}\right)\end{array}$ & $\begin{array}{c}\mathrm{V}_{\text {cell }} \\
(\mathrm{V})\end{array}$ & $\begin{array}{c}\text { Chlorides } \\
\text { passed } \\
(\mathrm{g})\end{array}$ & $\begin{array}{c}\text { Specific energy } \\
\text { consumed } \\
(\mathrm{kWh} / \mathrm{kg} \mathrm{Cl})\end{array}$ \\
\hline 1 & 300 & 6.35 & 0.0 & - \\
\hline 2 & 20 & 400 & 6.8 & 0.0 & - \\
\hline 3 & & 500 & 7.48 & 0.0 & - \\
\hline 4 & & 300 & 5.82 & 0.1 & 87.3 \\
\hline 5 & 30 & 400 & 4.88 & 0.1 & 97.6 \\
\hline 6 & & 500 & 6.71 & 0.0 & - \\
\hline 7 & & 300 & 3.85 & 1.7 & 3.40 \\
\hline 8 & 40 & 400 & 4.41 & 0.4 & 22.05 \\
\hline 9 & & 500 & 4.76 & 0.4 & 29.75 \\
\hline
\end{tabular}

Table 3.1 presents a summary of all the parameters and their values used in this study, in particular for an electrolyte flow rate of $1 \mathrm{~L} / \mathrm{min}$ and a testing time of 5 hours.

Table 3.2 gives the same parameters, but for a flow rate of $0.5 \mathrm{~L} / \mathrm{min}$.

Table 3.2.- Experimental results obtained with a flow rate of $0.5 \mathrm{~L} / \mathrm{min}$ and a testing time of 5 hours.

\begin{tabular}{|c|c|c|c|c|c|}
\hline $\begin{array}{c}\mathrm{T} \\
\left({ }^{\circ} \mathrm{C}\right)\end{array}$ & $\begin{array}{c}\text { Test } \\
\text { No. }\end{array}$ & $\begin{array}{c}\text { Current } \\
\text { density } \\
\left(\mathrm{A} / \mathrm{m}^{2}\right)\end{array}$ & $\begin{array}{c}\mathrm{V}_{\text {cell }} \\
(\mathrm{V})\end{array}$ & $\begin{array}{c}\text { Chlorides } \\
\text { transferred } \\
(\mathrm{g})\end{array}$ & $\begin{array}{c}\text { Specific } \\
\text { energy } \\
\text { consumed } \\
(\mathrm{kWh} / \mathrm{kg} \mathrm{Cl}-\end{array}$ \\
\hline & 10 & 300 & 3.82 & 0.5 & 11.5 \\
\hline 40 & 11 & 400 & 4.62 & 0.2 & 46.2 \\
\hline & 12 & 500 & 4.46 & 0.7 & 15.9 \\
\hline
\end{tabular}


Effect of electrolyte flow

Since this is a RED system, there is a chloride ion flow from the eluting solution to the anolyte as well as acid production in the anolyte from water oxidation. The formation of $\mathrm{HCl}$ is greater in all the tests because in the anolyte there is an initial chloride concentration. The objective of the system is to produce acid using the chloride ions that have crossed the membrane. Therefore, the following results consider only this parameter (Table 3.1).

It is important to stress that the net mass of chloride ions obtained is the result of two phenomena: on the one hand, there is a flow of chloride ions through the anionic membrane to the anolyte, and on the other there is an oxidation of these ions to gaseous chlorine at the anode. This can be visualized when the cell voltage is increased from V1 to V2, as schematized in Figure 3.1.

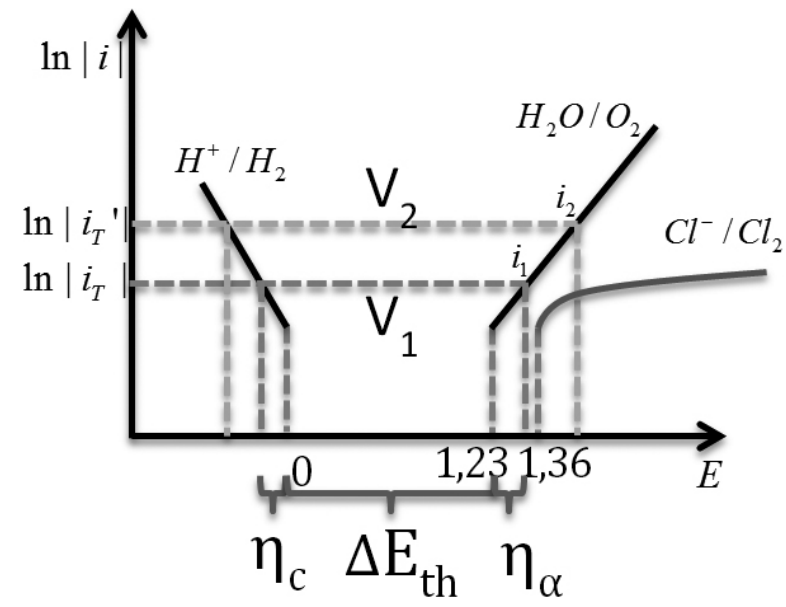

Figure 3.1.- Evans diagram for different cell voltages (V) and their corresponding current densities (i), where $\mathbf{V}_{2}>\mathbf{V}_{1}$ and $\mathbf{i}_{2}>\mathbf{i}_{1}$.

Effect of temperature

The results given in Table 3.3 show that as temperature increases, the net transfer of chloride ions increases considerably for all the current densities (see Figure 3.2)

Table 3.3.- Experimental results for a temperature of $40{ }^{\circ} \mathrm{C}$ and a testing time of 12 hours.

\begin{tabular}{|c|c|c|c|c|c|}
\hline $\begin{array}{c}\text { Flow } \\
\text { rate } \\
(\mathrm{L} / \mathrm{min})\end{array}$ & $\begin{array}{c}\text { Test } \\
\text { No. }\end{array}$ & $\begin{array}{c}\text { Current } \\
\text { density } \\
\left(\mathrm{A} / \mathrm{m}^{2}\right)\end{array}$ & $\begin{array}{c}\mathrm{V}_{\text {cell }} \\
(\mathrm{V})\end{array}$ & $\begin{array}{c}\text { Chloride } \\
\text { transferred } \\
(\mathrm{g})\end{array}$ & $\begin{array}{c}\text { Specific } \\
\text { energy } \\
\text { consumed } \\
(\mathrm{kWh} / \mathrm{kg} \mathrm{Cl})\end{array}$ \\
\hline 1 & 13 & 300 & 3.48 & 2.7 & 4.6 \\
\hline 0.5 & 14 & 300 & 4.52 & 0.3 & 54.2 \\
\hline
\end{tabular}

The temperature increase not only decreases the cell voltage (by increasing the conductivity of the electrolytes), as seen in Figure 3.3, but it also favors the mobility of ions through the membrane, finally increasing their net flow from the central to the anode compartment.

In Figure 3.4 it is seen that the specific energy consumption decreases drastically as the temperature increases. In fact, at $20^{\circ} \mathrm{C}$ and $30^{\circ} \mathrm{C}$ the consumptions are very high because there is almost no net flow of chloride ions. At a current density of $300 \mathrm{~A} / \mathrm{m}^{2}$ and $40{ }^{\circ} \mathrm{C}$ a particularly low value is reached with respect to all the others, $4.6 \mathrm{kWh} / \mathrm{kg} \mathrm{Cl}$.

On the other hand, although the cell potential decreases with increasing temperature, the effect of this voltage on the specific consumption is low.

The effect of the temperature on the electrochemical systems is large because they are processes that usually have a high activation energy and their kinetics is favored to a large extent by the temperature increase.

Effect of the flow rate

Working at constant temperature it can be seen that as the flow rate increases, there is an increase of the transferred chloride ion mass, because the transport of chloride ions by convection is favored. However, increasing the flow rate has another effect on the system, increasing the limiting current of the particular ion, which is reflected in a displacement of the curve of the parasitic reaction of the chloride to gaseous chlorine toward higher current densities, as seen in Figure 3.5, a phenomenon that depletes the anolyte of chloride ions.

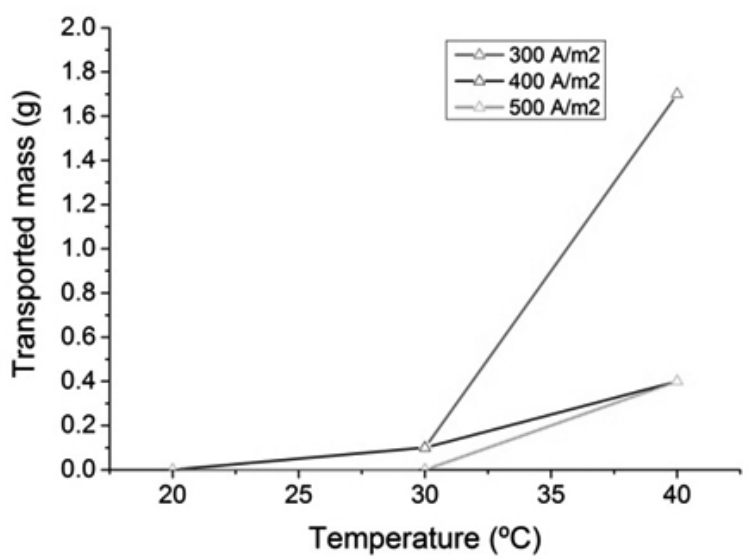

Figure 3.2.- Effect of temperature on the transported chloride mass at different current densities.

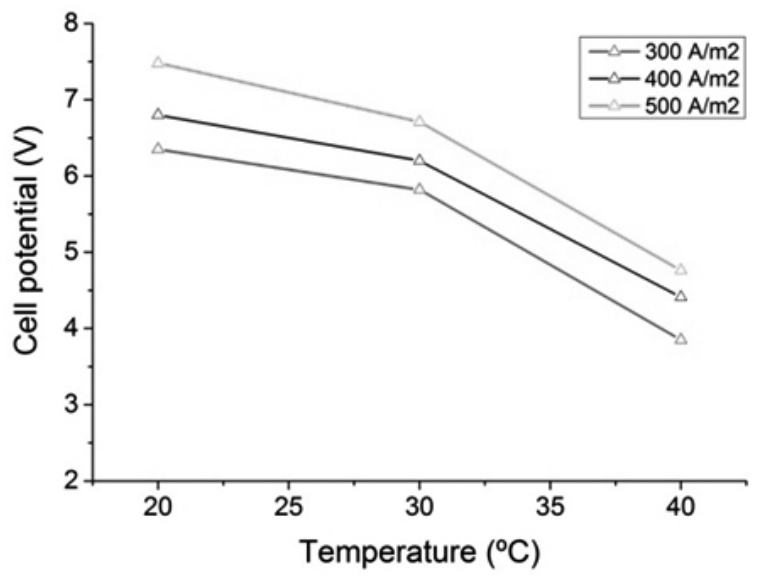

Figura 3.3.- Effect of temperature on cell voltage at different current densities.

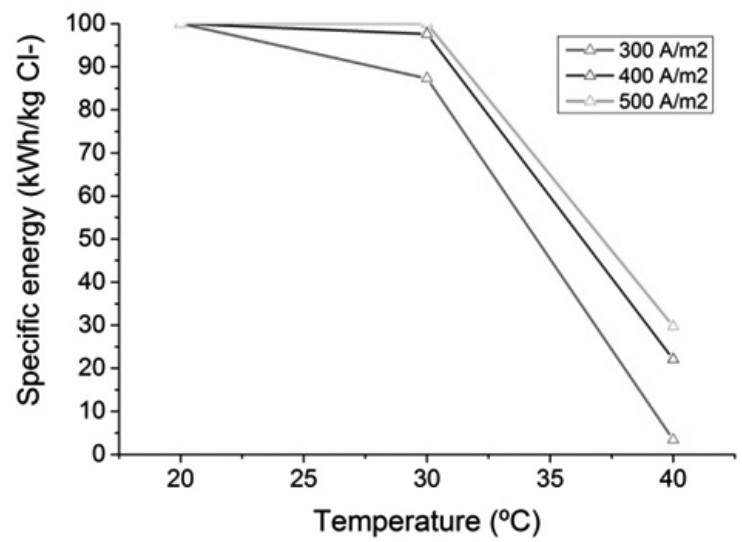

Figure 3.4.- Effect of temperature on specific energy consumption at different current densities for $1 \mathrm{~L} / \mathrm{min}$ 


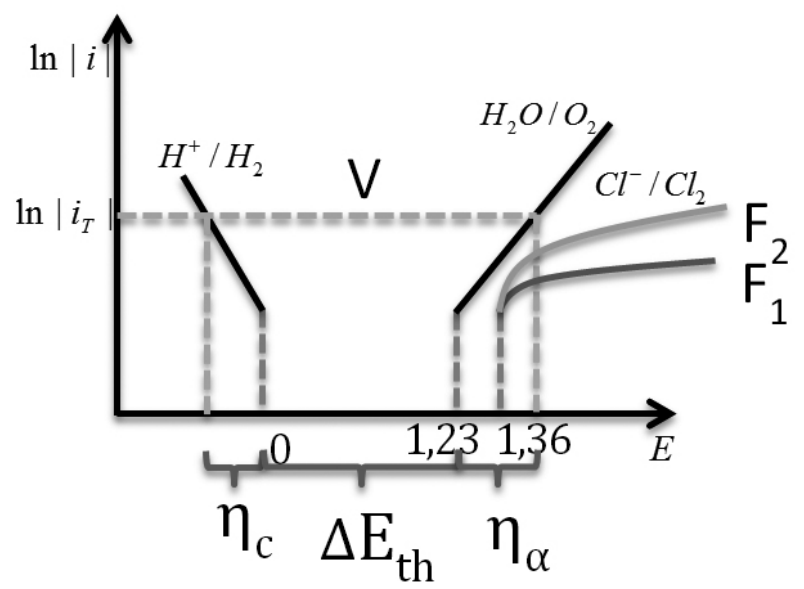

Figure 3.5.- Evans diagram for different flow rates $(\mathrm{F})$, where $\mathbf{F}_{2}>\mathbf{F}_{1}$.

According to Figure 3.6, at lower current densities the increased flow increases the ion mass obtained. As higher current densities are reached, particularly $500 \mathrm{~A} / \mathrm{m}^{2}$, as the flow rate in creases the parasitic reaction at the anode becomes more important than ion transport through the membrane, causing a decrease of the net chloride mass in the anolyte.

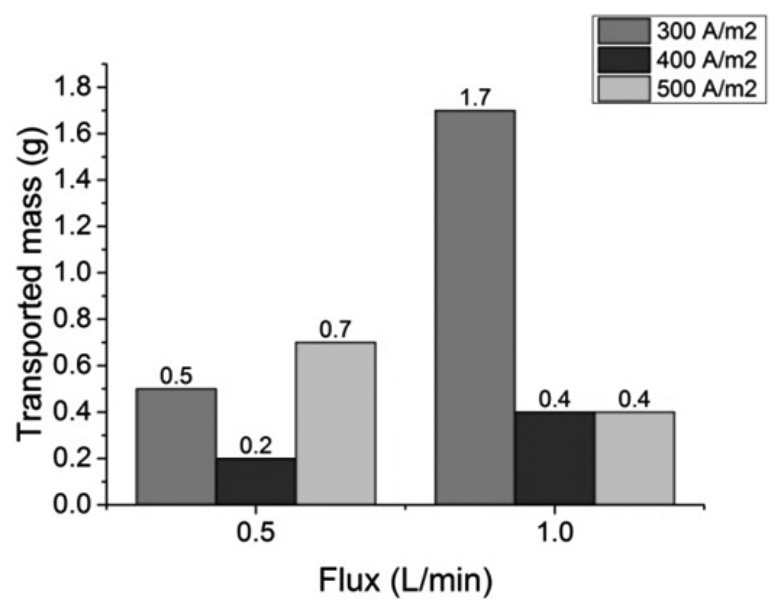

Figure 3.6.- Effect of flow rate on the transported chloride mass, at $40{ }^{\circ} \mathrm{C}$ and different current densities.

As shown in Figure 3.8, the specific energy consumption depends to a large extent on the transfer of ions through the anionic membrane, because the trend of the curves of Figure 3.8 is the opposite of those of Figure 3.4, while the cell voltages remain practically constant (see Figure 3.7). A difference is seen, however, in the specific energy consumption (Figure 3.8), because this parameter is associated with the mass of transported ions, as was shown in Figure 3.6, and it is inversely proportional to it, i.e., the greater the transported mass, the lower is the specific energy consumption.

\section{Effect of current density}

Working at constant flow, an increase of current density causes a decrease of the mass of chlorides transferred (see Figure 3.9) and an increase of the cell voltage (Figure 3.10). This is because at higher current current densities there is also a cell voltage increase, and then the parasitic oxidation reaction of chlorides at the anode becomes increasingly important, resulting in a greater consumption of ions in the anolyte, as was seen in Figure 3.1. At lower temperatures, the consumption of ions in the anolyte is greater than their flow across the membrane, getting a nil net transfer, as confirmed by the high specific energy consumption obtained during the tests, because the net chloride mass is so low that it allows this value to increase substantially with respect to tests at higher temperatures.

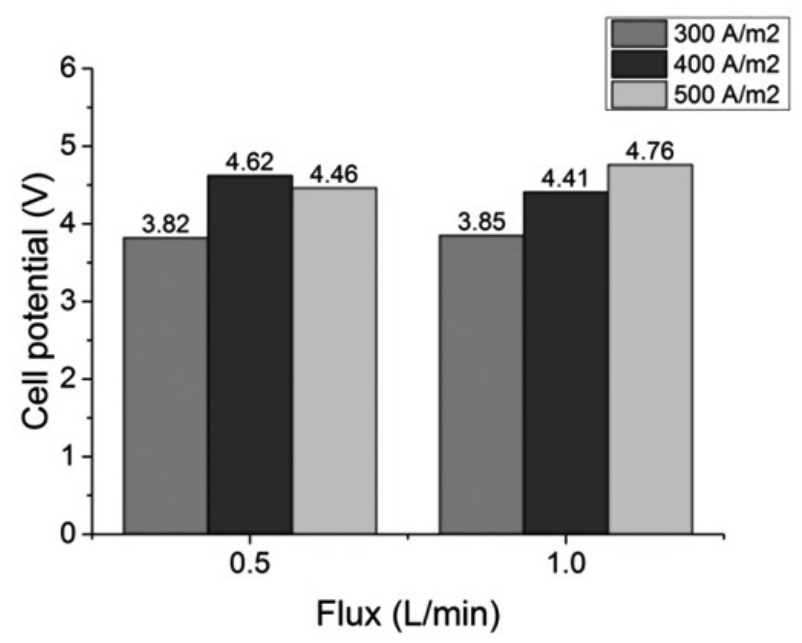

Figure 3.7.- Effect of flow rate on cell voltage at $40{ }^{\circ} \mathrm{C}$ and different current densities.

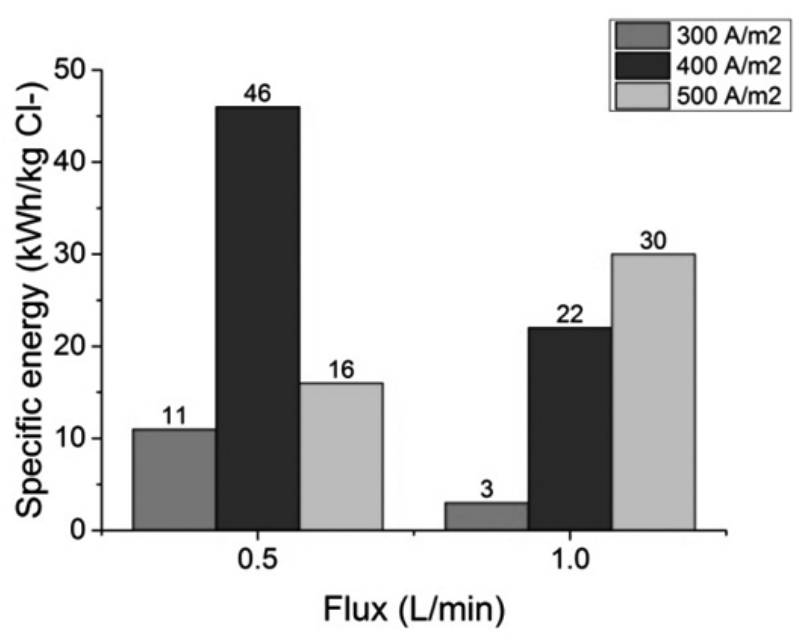

Figure 3.8.- Effect of flow on the specific energy consumption at $40{ }^{\circ} \mathrm{C}$ and different current densities.

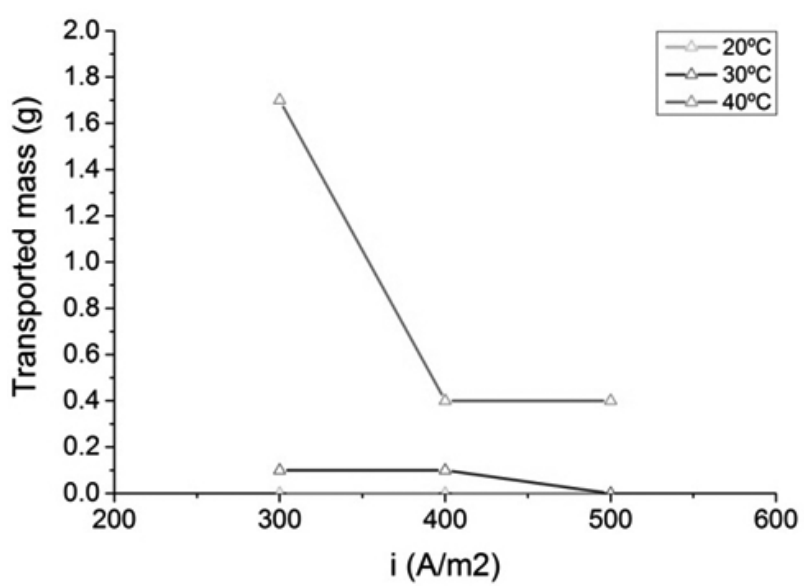

Figure 3.9.- Effect of current density on the transported chloride mass at diferent temperatures. 


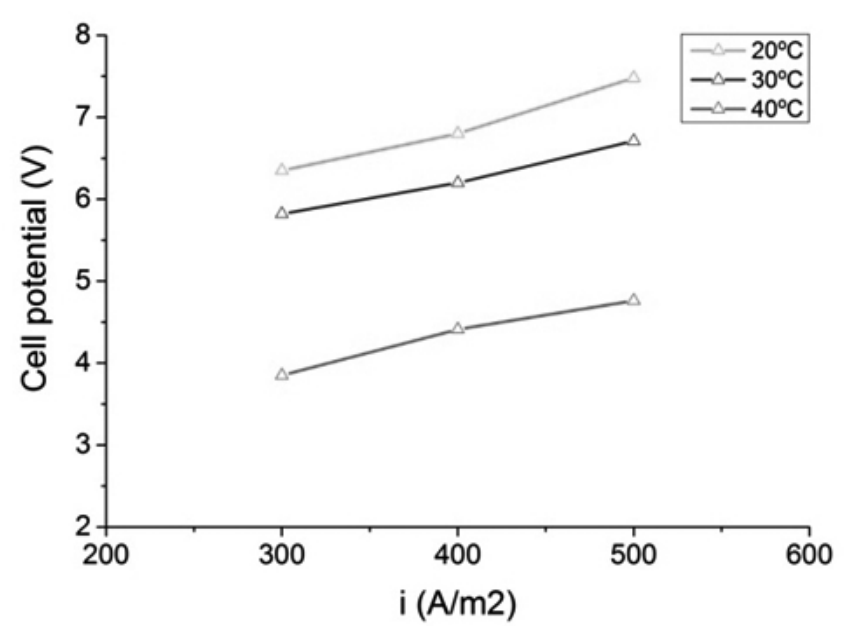

Figur3 3.10.- Effect of current density on cell voltage at different temperatures.

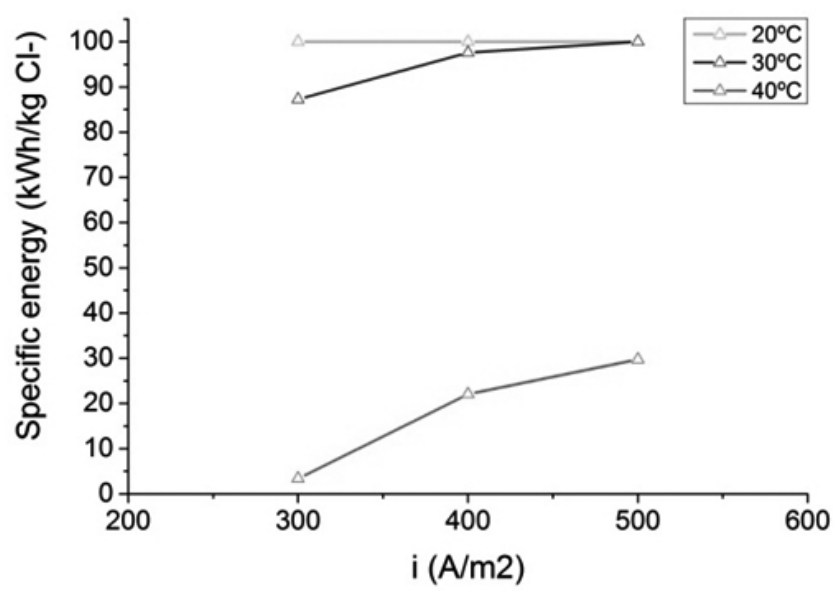

Figure 3.11.- Effecto of current density on specific energy consumption at different temperatures.

In brief, it is possible to mention that the cell voltage (Figure 3.10) as well as the specific energy (Figure 3.11) increase with increasing current density. As shown in Figures 3.10 and 3.11, the amount of energy that must be applied for the operation of the system is too high to make it a viable alternative to fractional distillation at low temperatures.

\section{CONCLUSION}

It can be concluded that it is possible to recover clean hydrochloric acid from an eluting solution using reactive electrodialysis and working at low current densities and high temperatures, in this way avoiding the operational problems of the fractional distillation process.

Both parameters, current density and temperature, play a fundamental role in the proposed system, because they are the parameters that make it possible to avoid the parasitic oxidation reaction of chloride ions, improving the efficiency of the process.

\section{ACKNOWLEDGEMENTS}

The authors acknowledge with thanks the support given to this work by Sección de Geología y Minería of Comisión Chilena de Energía Nuclear (CCHEN) and by Departamento de Investigaciones Cientificas y Tecnológicas (DICYT) of Universidad de Santiago de Chile.

\section{REFERENCES}

1.- G. Cifuentes, Teoría y práctica de la electrometalurgia, Apuntes de Asignatura, $1^{\circ}$ edition, Facultad de Ingeniería, Departamento de Ingeniería Metalúrgica, Universidad de Santiago de Chile, Santiago, 2010.

2.- K. F. Streit, Estudo da aplicação de procesos de separação com membranas no tratamento de efluentes de curtume: nanofiltraçao e eletrodiálise, tese de Doutorado, Escola de Ingeniería, Programa de Pós-Graduação em Engenharia de Minas, Metalúrgica e de Materiais, Universidade Federal do Río Grande do Sul, Porto Alegre, Brasil, 2011.

3.- J. Llorens, Tecnología de Membranas, Apuntes de Curso Impartido en Universidad de Barcelona, España, 1992.

4.- Davis, Samuel M., Electrochemical splitting of sodium sulfate, tesis para grado de magister, Instituto Tecnológico de Georgia,USA, 2006.

5.- P. G. Schirg, Introduction a la teoría y práctica de la Técnica de Membranas, PS Prozesstechnike GMBH. www.membran.com.

6.- R.S. Ramalho, Tratamiento de Aguas Residuales", Capítulo 8, Editorial Reverté, Barcelona, 1993.

7.- F. Walsh, Un primer curso de Ingeniería Electroquímica, Editorial Club Universitario, España, 1993.

8.- S. Koter, A. Warszawski, Polish Journal of Environmental Studies. 9, 1, (2000).

9.- Xu, Tongwen, Journal of Membrane Science. 263, 1-2, (2005).

10.- Baker, Richard W., Membrane technology and applications, capítulo 10: membranas de intercambio iónico en procesos de electrodiálisis, Edited by John Wiley \& Sons, Ltd., $2^{\circ}$ edition, California, USA, 2004.

11.- Pérez Herranz, Valentin, Determinación de propiedades de transporte en membranas de intercambio iónico, Workshop Membrane Processes for Industrial Pollution Control with Water and Product Recovery, 23, IST Congress Centre, Lisbon, Portugal, 2013.

12.- G. Cifuentes, J. Simpson, F., Lobos, L. Briones, A. Morales, J. Chil. Chem. Soc., 54, 4 (2009). 